\title{
Quantifying tax subsidies to shipping
}

\author{
Olaf M. Merk ${ }^{1}$
}

Accepted: 26 October 2020 / Published online: 5 November 2020

(c) Springer Nature Limited 2020

\section{Introduction}

The shipping industry has a long history of state support via maritime subsidies. These subsidies consist of monetary aid of state bodies to shipping companies, in various forms. Subsidies can be granted for a particular service and under specific conditions, or without strings attached. Often, the boundary between conditional and unconditional subsidies is difficult to draw, e.g. subsidies for postal services by ship in the late nineteenth century were often so generous that they could be considered mostly general aid rather than a subsidy provided for a specific service (Meeker 1905). Tax subsidies form part of a larger group of maritime subsidies: the subsidy consists of the tax revenues foregone (for the state) due to a tax deduction or exemption for shipping companies. So, rather than a direct transfer of funds from the state to the company, a tax subsidy is essentially aid in the form of a lower tax burden for shipping companies, compared with non-shipping companies.

Tax subsidies for the shipping industry have emerged over the last few decades. While maritime subsidies have become almost universally applied in maritime nations since the 1870 s, most of these were subsidies via state expenditures. An example is the Operating Differential Subsidy (ODS) in the USA (Jantscher 1975). Rarely was there state support in the form of tax subsidies (Jones 1916; Saugstad 1932). More recently, however, tax subsidies have become the main vehicle to support the shipping sector. This is mainly related to the emergence of open registries [flags of convenience (FOCs)], offering favourable tax treatment to shipping companies, often practically zero tax rates. Shipowners have massively used this as a possibility for tax avoidance by registering their ships under these flags. This provoked the established maritime nations to offer similarly generous tax exemptions to shipping companies in order to make it attractive to shipowners to re-flag their vessels under the flags of the countries where they are genuinely linked. One of the main tax exemptions for shipping-and the subject of this editorial-is an exemption from corporate income tax that shipping companies can acquire if they opt for a

Olaf M. Merk

olaf.merk@itf-oecd.org

1 International Transport Forum (ITF), Organisation for Economic Co-operation and Development (OECD), 2, rue André Pascal, 75016 Paris, France 
tonnage tax scheme. This is a shipping-specific tax scheme that is very favourable to the shipping sector. In 1990, only Greece had a tonnage tax; now, 22 other European countries have the same.

The emergence of tax subsidies in shipping has arrived together with an increase in literature on the taxation of shipping. The first group of studies consisted of descriptions and analyses of taxation regimes in general and in individual countries (Gardner and Richardson 1973; Marlow and Mitroussi 2012; Maisto (ed.) 2017; EY 2016). Comparative studies are rare (Stevens 2017; Weber and Van de Sande 2017 are examples) and mostly outdated (Gardner and Marlow 1983; Mayr and McGrath 1997). There is an abundance of academic articles on shipping tax regimes in individual countries, such as the USA (Farr 2014), Greece (Marlow and Mitroussi 2008; Matsos 2009; Merika et al. 2019; Panagiotou and Thanopoulou 2019), UK (Brownrigg et al. 2001), Canada (Brooks and Hodgson 2005), Taiwan (Chiu 2007), China (Wan 1988), Germany (Elschner 2009), South Korea and Japan (Yang 2014). A second group of literature covered the impacts of shipping-specific tax regimes, such as impacts on investments in ships (Marlow 1991a, b, c; Evans 1984; Glen 1996; McWilliams et al. 1995), on seafarer employment (Gekara 2010), choice of flag (Bergantino and Marlow 1998; Marlow and Mitroussi 2011; Kavussanos and Tsekrekos 2011; CEBR 2017) and balance of payments (Gardner 1975; Haralambides 1989). The Dutch government has commissioned various studies on tax exemptions for shipping (Deloitte 2006; Ecorys 2007a, b; Panteia 2014), and so have the German (Elschner 2009) and the Norwegian governments (Econ 2010). Every year, the Swedish government releases an assessment of the main impacts of the (subsidised) shipping sector (Trafikanalys 2019). The third group of literature consists of assessments of tax subsidies in the context of wider societal goals. This literature, fairly limited in size, questions the justifications of tax exemptions for shipping (Moyer 1977; Danish Economic Council 2006; Selkou and Roe 2002; Leggate and McConville 2005) and is, in this sense, related to a larger literature that has critically assessed the justification of maritime subsidies and protective shipping policies (see for example Meeker 1905; Siegert 1930; Lawrence 1966; Sturmey 1975; Goss and Marlow 1993; Sletmo 2001). In this context, one could also mention articles on shipping and taxation from investigative journalists (e.g. Bergin 2015; Gibbs 2017).

Despite the large literature, no quantitative overviews of tax subsidies for shipping exist to date. It is thus impossible to know what the shipping industry pays in taxes, what it would have paid under a conventional fiscal treatment and what exactly is the tax subsidy that states grant to their shipping sectors. There are probably several reasons for this absence of transparency. An obvious one is that tax subsidies are difficult to measure; unlike subsidies via direct expenditure, tax subsidies do not have a budget line in the general budget of a government from which money is transferred to recipients. Instead, tax subsidies relate to foregone revenue, i.e. revenue that would have otherwise come in, thus being much less visible. This was already the case in the past, even in the admirably comprehensive studies on maritime subsidies at the end of the nineteenth and beginning of the twentieth century (see in particular Jones 1916; Saugstad 1932), the then existing tax subsidies were mentioned but not actually quantified. Moreover, the widespread emergence of tax 
subsidies in recent decades coincides with the discontinuation of international overviews of maritime subsidies, as those provided by the US Department of Commerce.

Yet, we think that the quantification of tax subsidies to shipping is highly relevant, as this would help to explain global economic integration and design better policies. The economic analysis of globalisation has largely ignored the existence of shipping subsidies. Whilst many authors have linked economic globalisation to a decline in maritime transport costs, these cost decreases have been mostly linked to economies of scale (Jansson and Shneerson 1982; Cullinane and Khanna 1999, 2000; ITF 2015; Haralambides 2019) and maritime transport innovations, such as the invention of the steamship (Knauerhase 1968; Harley 1988; O'Rourke and Williamson 1999; Pascali 2017), ship design (Luiten van Zanden and Tielhof 2009), labour productivity increases (Lottum and Luiten van Zanden 2014), containerisation (Levinson 2006; Hummels 2007; Bernhofen et al. 2016; Kerim Cosar and Demir 2018) and reductions in transaction costs due to state intervention (North 1958, 1968, 1991).

However, it is not unthinkable that direct and indirect maritime subsidies have considerably lowered the cost of trade, and in this way have accelerated global economic integration. It is often claimed that one of the frustrations with globalisation is the unfairness of tax systems, with multinational enterprises scheming to pay as little tax as possible. It is argued that the result of lower tax revenues leads to pressures to cut budgets for public services and social security (Rodrik 2018; Milanovic 2019; Saez and Zucman 2019). Efforts to measure the degree of global tax avoidance have intensified over the past few years (see for example Zucman 2013). Yet, numbers on tax avoidance in the shipping sector hardly exist, which in a way is ironic, considering that shipping has historically enjoyed fairly favourable tax treatment. The shipping industry might eventually be covered by a minimum tax to be applicable to other multinational enterprises, as currently proposed by the OECD/ G20 (OECD 2020). Within the context of that proposal, it would be essential to understand the current tax burden of the shipping sector and the implications that a minimum tax could have. This editorial aims to increase that understanding.

Such a quantification of maritime tax subsidies could help to improve related policies. The EU has established its maritime state aid guidelines that should-as the term indicates-provide guidance to policymakers on how much state aid ought to be allowed. Yet, the guidelines contain provisions that are very difficult to implement without the quantification of tax subsidies. An example is chapter 11 of the 2004 EU Maritime State Aid Guidelines, which stipulates that maritime state aid '... should not exceed the total amount of taxes and social contributions collected from shipping activities and seafarers' (EC 2004). In practice, this has never constrained the European Commission to approve new state aid, even though no EC study has ever quantitatively shown that this requirement has been met.

Quantification of shipping tax subsidies could also shed light on regular complaints of shipping associations, like the International Chamber of Shipping, that third countries, such as South Korea, distort the market for maritime transport with their subsidies (ICS 2020). Such assumptions of market distortions also underlie the 2020 White Paper on foreign subsidies by the European Commission (EC 2020). All such discussions are highly hypothetical without numerical data on maritime 
subsidies, neither budgetary measures nor tax subsidies; our objective here is to address this void, at least to a certain extent that, hopefully, shall be appreciated by the MEL readership.

\section{Existing data: scope, availability and limitations}

Tax subsidies are the difference between what firms would normally pay in taxes, and what shipping actually pays. In other words, it is the revenue foregone to state coffers due to the tax subsidy. In some cases this is relatively easy to calculate, especially when the shipping sector is fully tax exempt, when this exemption is globally applied, or when there is no doubt about the tax base, i.e. a situation that requires a limited amount of data, most of which are publicly available. An example is the tax exemption for fuels for international shipping. In other cases, data availability is much more limited, something that complicates quantification.

A tax subsidy that is particularly difficult to quantify due to data limitations is related to corporate income tax, which is the focus of this editorial. Some countries exempt, either fully or partly, shipping companies from corporate income taxation. Many countries apply a shipping-specific tax, known as tonnage tax, which has the tonnage of a ship as the tax base instead of the ship's profit, as is normal practice with other land-based firms. It should be mentioned that the tonnage tax scheme has an anti-cyclical nature, something that comes in handy in an industry such as international shipping, which is notoriously volatile and cyclical. An owner that opts for the scheme must commit their tonnage for a number of years. The tonnage tax thus allows them to even out market fluctuations in the sense that, although they enjoy fairly low taxes, comparatively, they still need to pay a fixed (tonnage) tax, even in periods of worrisome economic downturns. In the case of such tax subsidies, various data are lacking that are needed to assess the difference between what shipping companies are paying and what they would have paid if they were a non-shipping company. In both situations, the tariff and the tax base need to be known. Furthermore, although tariffs are publicly available, data on the tax base are much less so.

The rates for corporate income taxes and tonnage taxes are publicly available. In most countries, this information is part of tax laws and regulations, and there are various publications that give an overview of these rates. Most tonnage taxes apply the regular corporate tax rate, but instead of using the actual profit of a shipping company as the tax base, they define a hypothetical (notional) profit based on the tonnage of the firm's fleet. These notional profits in each country are well known. This type of tonnage tax is often called a Dutch tonnage tax scheme, after the Dutch introduced it in 1996. An aspect that causes some confusion is in regards to countries such as Greece, Cyprus and Norway, which although they apply a tonnage tax similar to that of the Dutch, i.e. taking tonnage as the tax base, use a tax rate that is not the regular CIT rate but one that varies with the tonnage of the ship. These rates are known too. This type of tonnage tax is known as the Greek model, after Greece introduced it in 1975. It is possible to compare the tax burden of the two models at ship-level, by comparing the tax burdens for similar ships in different countries (Fig. 1). The European Commission has sometimes used the difference between the 


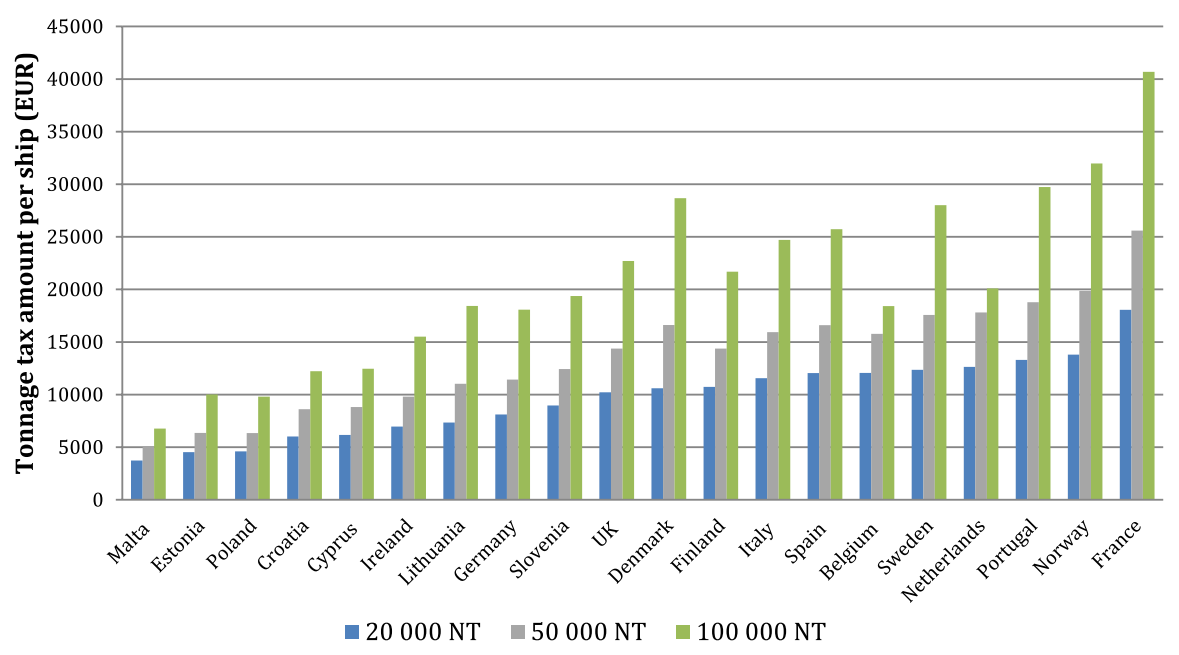

Fig. 1 The tax burden per ship (according to net tonnage) under different tonnage tax schemes. Source author's elaboration based on country tonnage tax schemes. Note Greece is not included in this figure because its scheme has tariffs per gross registered tonnage (GRT) instead of net tonnage (NT), which makes it difficult to compare with other European schemes

two types of tonnage tax to make rather ambiguous comparisons between schemes in its decisions on tonnage tax schemes in EU member states. What complicates matters more is that various schemes provide the possibility for further reductions, for example related to the age and size of the ships, or to their environmental performance.

Although comparisons at ship-level are possible, it is much more difficult to say something at country level. Only a few countries-Norway, Netherlands, United Kingdom, Ireland, Malta and Cyprus-have collected or released figures on how many ships benefit from their tonnage tax (Table 1). In many cases, there is no link between tonnage tax, national flag and the nationality of the shipowner. Unsurprisingly, hardly any country presents government budgets with revenues from tonnage taxes, also because these are usually very small. For instance in the UK, tax revenue from tonnage taxes represented around GBP 5 million in 2013.

Equally, little is known on what shipping companies would have to pay in taxes if they were treated as non-shipping companies. Corporate income tax rates are, of course, publicly available, but the difficult part is the tax base, i.e. the shipping companies profits that would need to be taxed. Tax administrations ought to be able to extract this information, but this is hardly ever done or made public. Nonetheless, we have been able to find this information for the UK, the Netherlands and Cyprus.

Governments often come up with an estimate of revenues foregone at the introduction of a new tax subsidy. This is usually based on an assessment of the profits that would normally be taxed, compared with an estimate of the taxes to be paid under the new scheme (the difference of the two is the revenue foregone). Such estimates are incorporated in government budgets of many countries and also in notifications to the European Commission of maritime state aid. Sometimes these 
Table 1 Utilisation of tonnage tax schemes in various countries

\begin{tabular}{|c|c|c|c|c|}
\hline Country & Number of ships & Number of companies & Year & Source \\
\hline \multirow[t]{9}{*}{ Norway } & 709 & & 2007 & EFTA (2017) \\
\hline & 963 & & 2008 & \\
\hline & 1152 & & 2009 & \\
\hline & 1200 & & 2010 & \\
\hline & 1419 & & 2011 & \\
\hline & 1422 & & 2012 & \\
\hline & 1452 & & 2013 & \\
\hline & 1484 & & 2014 & \\
\hline & 1523 & & 2015 & \\
\hline \multirow[t]{5}{*}{ United Kingdom } & $>800$ & 285 & 2007 & UK Rep EU (2006-2009, 2014) \\
\hline & $>800$ & 283 & 2008 & \\
\hline & $>900$ & 311 & 2009 & \\
\hline & $>900$ & 322 & 2010 & \\
\hline & $>800$ & 246 & 2015 & \\
\hline \multirow[t]{3}{*}{ Ireland } & 104 & 20 & 2008 & IMDO $(2010,2011)$ \\
\hline & 154 & 36 & 2009 & \\
\hline & 276 & 45 & 2010 & \\
\hline Cyprus & 3300 & 49 (ship management) & 2016 & EC (2019) \\
\hline Malta & 462 & & 2015 & EC (2017) \\
\hline Netherlands & 595 & & 1996 & Ecorys (2007a) \\
\hline
\end{tabular}

schemes are evaluated and adapted to take into account realities that were different from assumptions. Subsequent evaluations of the Dutch tonnage tax scheme, for example, showed that estimates of tax revenues foregone were systematically lower than what was originally estimated (Table 2). Such revisions are fairly rare among countries.

Sometimes, countries take a different approach when estimating revenues foregone from shipping-specific taxes. Instead of comparing the shipping scheme with the tax treatment of ordinary firms, they compare shipping taxes with the shippingspecific measures that were in place before. In other words, revenues foregone are considered as the revenue loss due to the new measure, compared with the situation before the introduction of the new measure. Several observers (e.g. Jantscher 1975) have noted that the shipping sector has already benefited from favourable tax

Table 2 Differences between budgeted and actual revenue foregone of the Dutch tonnage tax

\begin{tabular}{lll}
\hline Period & $\begin{array}{l}\text { Budgeted annual foregone } \\
\text { revenues (EUR million) }\end{array}$ & $\begin{array}{l}\text { Actual annual foregone } \\
\text { revenues (EUR million) }\end{array}$ \\
\hline $1997-1999$ & 11 & 59 \\
$2003-2005$ & 50 & 92 \\
$2007-2011$ & 80 & 153 \\
\hline
\end{tabular}

Source ITF (2019) 
treatment - for example in the form of accelerated depreciation allowances-before the introduction of a tonnage tax. In this sense, the revenue foregone due to the tonnage tax may have been underestimated, if compared with previous periods, but could nevertheless be considerable if compared with the tax treatment of ordinary companies. The European Commission seems to have tolerated this approach to estimating revenue foregone in various of its decisions on tonnage tax schemes (see for example EC 2010). As a result, the officially declared tax subsidies related to schemes such as those of Greece, Cyprus and Malta, might be lower compared with other tonnage tax schemes in the European Union, such as those of the Netherlands, Germany and France (ITF 2019).

In conclusion, for most countries, no public (government) data are available that can be used to calculate tax subsidies to shipping. These data limitations could be solved if governmental tax administrations would provide more fine-grained data. However, this would not solve one problem that we have currently excluded, namely the possibilities of tax avoidance via shipping-specific tax havens, i.e. open registries (FOC).

\section{Tax avoidance via flags of convenience}

Flags of convenience (FOC) are the result of the post-WWII convergence of the interests of US shipowners and the US government. For shipowners, open registries provided ways to avoid taxation and regulation. For the US government, FOCs provided an interesting option to further the interests of their shipping sector, particularly the tanker sector, driven by oil majors, without having to directly subsidise it. The promoters of FOCs even used the unlikelihood of developed countries to provide more maritime subsidies as an argument for allowing flags of convenience (Naess 1972; Carlisle 1981, 2017). Presently, the largest open registries are those of the Marshall Islands, Liberia and Panama, all offering tax-exemptions to foreign shipping companies and the possibility to hide beneficial owners from the tax authorities of the FOC, or from those of the country of fiscal domicile of the owner. Often, the latter country may be also offering favourable income tax concessions to persons of a certain wealth (Bergin 2015). For the flag state, the FOC facility provides a source of revenue, albeit small. For example in 2016, revenues to the registry of the Marshall Islands brought in USD 5 million in government revenue (Republic of the Marshall Islands 2016). In Panama, the shipping registry was found to be associated with the lowest economic value-added among the different constituents of the country's maritime cluster (Intracorp 2014).

Many of the tax exemptions in the developed world have been put in place as a reaction to the tax exemptions of FOCs. For example, re-flagging has been a recurrent motivation for maritime state aid, as formulated in the various EU maritime state aid guidelines (EC 1997, 2004). This is relevant to our subject. Tax avoidance via flags of convenience does not show up as a tax subsidy in any account, although it clearly represents tax revenues foregone. Paradoxically enough, and this was the sentiment at the introduction of the tonnage tax in the Netherlands in 1996, if a 
country manages to re-flag some ships thanks to a tonnage tax, this could be considered a reduction in tax revenues foregone.

Recent approaches have estimated the extent of tax avoidance and evasion by analysing the inconsistencies in international financial statistics-the difference between liabilities and financial assets reported in world financial centres (Zucman 2013, 2015). This could potentially also provide a possibility for estimating the tax avoidance of the shipping industry, if fine-grained data would be available that would make it possible to identify the shipping sector in these accounts. This is not the case for the moment. Somehow, a quantification of tax subsidies needs to take the effect of tax avoidance via flags of convenience into account. We develop a methodology below.

\section{An alternative quantification approach}

Our approach is based on data available in annual reports, financial statements and audit reports from individual shipping companies. On the basis of these, we have built a database of financial data over the period 2005-2019, of 157 global shipping firms active in the main shipping sub-sectors in 41 different countries. In addition, our database includes 40 terminal operators and 24 logistics companies.

All of the financial reports that form the basis of our database contain "profits before tax" and tax expenses. In some cases, these reports provide figures on tax reconciliation, which shows the taxes that the company would have to pay if the CIT rate of the country where the company is incorporated would be applied. In some cases, the financial reports include the amount of tonnage tax expenses that were paid, which are often reported under operational expenses rather than tax expenses. In our database, we do not take into account the fact that some countries also provide generous depreciation regimes to their shipping sector, something that of course allows the limitation of shipping profit to be taxed. Quantifying these tax subsidies merits a separate study.

A methodological challenge regards the question of what constitutes a 'shipping company'. The answer is clear when a company focuses exclusively on a specific sea-transport activity. In practice, this is not often the case. In bulk shipping, for example, some of the largest shipping companies are oil, gas and mining companies, for which shipping represents an essential but fairly minor activity in terms of profits. There are also many shipping companies that have diversified into other activities that are often related to shipping but cannot be considered to be part of it, such as shipbroking, logistics, warehousing, land transportation, freight forwarding, cargo handling in ports, port services, real estate, manufacturing or extractive activities. Finally, there are some shipping conglomerates that are active in several shipping sectors, such as container shipping, bulk shipping and car transport, but present their tax expenses only for the whole group. All these cases present challenges, insofar as it is difficult to identify the profit and tax burden for the shipping sub-sector in question.

Annual financial reports occasionally split out profits related to the different activities in their segment reporting, but this is rarely done for the tax expenses. 
In most cases, it is impossible-based on the annual reports-to clearly identify the effective tax rate of the shipping part of such companies. For this reason, our data collection has focused on companies for which shipping represents a predominant activity, and for which the profits and tax expenses per shipping sector can be identified. Shipping profits can be highly volatile which could lead to an over- or underestimation of the effective tax rate. In order to minimise the possibility that incidental effects skew our estimates, we have taken the average score over 15 years (2005-2019), so as to spread incidental effects over time, whenever these data were available.

Another challenge is that not all shipping companies release annual financial reports. For a considerable part of shipping companies, no financial data are publicly available. However, one would not be unreasonable to assume that, grosso modo, the firms not covered in our dataset have similar effective tax rates.

The challenges related to data collection are also reflected in the composition of our database. Ideally, all major shipping companies in the main shipping sectors would have been included. In practice, data for several of them are not available, or only available at a highly aggregated level or for a limited period of time, which renders them useless for our purposes. The "Annex" at the end provides an overview of the companies included in our database.

We use the collected data to estimate overall profits and tax expenses of the shipping industry. As previously mentioned, we assume that the profits and tax expenses per shipping sector found in our data collection can be considered representative for the different shipping sectors (container, liquid bulk, dry bulk, Ro-Ro and cruise shipping). For each company in the database, we collected data on its fleet capacity to know the extent of coverage of our dataset and to be able to extrapolate total profits and tax expenses to the level of shipping sectors. Capacity data used were the deadweight tonnage of the fleet (for dry bulk and liquid bulk), TEU capacity (for container shipping), passenger capacity (for cruise shipping), car capacity (for car carriers) and gross tonnage (for ferries).

These data allow us to show the amount of taxes paid by the various shipping sectors and shipping as a whole, and the effective corporate income tax rates. We confront this actual situation with three different scenarios to assess the revenue foregone:

The first scenario assumes that there will be a minimum tax for multinational companies, which implies that all shipping companies will pay at least this minimum tax-hereby defined as $12.5 \%$ - on their profits. We further assume that the shipping companies currently paying more than $12.5 \%$ will continue to do so.

In the second scenario, shipping would be taxed like the port terminal sector. This scenario looks at the difference in actual tax rates between the port and shipping sector as a whole and considers this as revenue foregone.

In the third scenario, shipping would be taxed according to the average corporate tax rate in OECD countries (23.7\% in 2018). The revenue foregone here is the difference between the taxes the shipping sector would have paid under a $23.7 \%$ rate on overall profits of the main shipping sectors and the actual tax expenses paid. 


\section{Main findings}

Based on an analysis of our dataset of 157 shipping companies over the period 2005-2019, we find that shipping firms pay approximately USD 1.9 billion in corporate income tax per year, including tonnage taxes. Over the same period, the global shipping sector enjoyed net profits (before tax) of around USD 27 billion p.a.. This means that the effective tax rate for the shipping sector is currently around $7 \%$. The shipping sector with a particularly low effective tax burden is cruise-shipping, with an effective tax rate of $0 \%$. Other shipping sectors with low effective tax rates are the liquid bulk sector (including oil tankers, product, chemical tankers and gas carriers), the roll on-roll off (Ro-Ro) sector (both 3\%) and the dry bulk sector (6\%). The shipping sector with a relatively high effective tax rate is container shipping (19\%). Shipping has considerably a more favourable tax regime than other parts of the maritime supply chain, such as port operations, freight forwarders and logistics companies. Port operators have an average corporate tax rate of $20 \%$, freight forwarders and logistics operators a rate of $27 \%$. There are considerable differences between world regions. We observed the lowest tax burdens for shipping companies incorporated in Oceania (0\%), North America (0\%) and Latin America and Caribbean (1\%). The highest overall effective tax rates were observed for shipping companies incorporated in Europe (11\%) and Asia (12\%). The Middle East occupies a middle position, with an effective tax rate of $8 \%$ for shipping companies incorporated there (Table 3).

Global tax revenues from shipping would amount to USD 4.4 billion if there would be a minimum tax of $12.5 \%$ (scenario 1). In the case where shipping would be taxed like the port terminal sector, that is $20 \%$ on average, total global tax revenues

Table 3 Effective tax rates of shipping sectors

\begin{tabular}{lc}
\hline & $\begin{array}{l}\text { Effective } \\
\text { tax rate }(\%)\end{array}$ \\
\hline Shipping & 7 \\
Port terminal operations & 20 \\
Freight forwarding and logistics & 27 \\
Shipping sectors & \\
Cruise shipping & 0 \\
Liquid bulk & 3 \\
Roll on/roll off & 3 \\
Dry bulk & 6 \\
Container shipping & 19 \\
Shipping firms, incorporated in: & \\
Oceania & 0 \\
North America & 0 \\
Latin America and Caribbean & 1 \\
Middle East & 8 \\
Europe & 11 \\
Asia & 12 \\
\hline
\end{tabular}


would amount to USD 5.4 billion. In the third scenario, in which shipping would be taxed according to the average corporate tax rate in the OECD, the shipping sector would pay USD 6.5 billion in taxes. Based on these three scenarios, one could consider that the corporate tax subsidies for shipping (tax revenue foregone) range from USD 2.5 billion per year for scenario 1, to USD 3.5 billion per year for scenario 2 and USD 4.6 billion for scenario 3 (Table 4). In other words, the shipping tax revenue foregone over 2005-2019 represents USD 38-69 billion.

\section{Interpretation of findings}

An interpretation of these results needs to start with a caveat on the data presented in the previous section. The estimated effective tax rate depends, to a large extent, on the profits from firms at a specific point it time. As shipping sectors are highly volatile, there is considerable variation in profits and losses that could skew the calculations. Considering that tax expenses remained more or less stable over these periods-partly thanks to tonnage taxes - the large losses over a certain period could lead to overestimations of the effective tax rate of shipping sectors. For example 2014, 2015 and 2016 were particularly unprofitable years for dry bulk shipping, and 2009, 2011 and 2016 for container shipping. This could explain the relatively high effective tax rates for these sectors compared with other shipping sectors. Ideally, the collection of shipping profits and tax expenses data should be undertaken over a long period, of which, however, data are not always available.

Contrary to observations that shipping is essentially a zero-taxed sector (see for example Knudsen 1997), we find that the shipping industry on the whole actually pays taxes, even if the majority of shipping firms in our database (57\%) had a tax burden of zero (or actually received tax credits). Only the cruise shipping sector pays virtually no corporate income taxes, most other shipping sectors pay some taxes, although to a considerably lesser extent than many other economic sectors. It should be noted here that shipping companies might pay (more) taxes because they have taken up activities in addition to shipping that are normally taxed. In particular, this could be the case for container shipping companies that often also offer logistics activities that are usually not tax-exempted, as is the case of shipping activities. This explains to a large extent the higher tax rate for container shipping. In almost all financial statements, these logistics activities are presented as part of container shipping activities - and not as distinct categories. In the rare cases where they are presented separately, the tax expenses are not assigned to logistics and container shipping separately. Even if an emerging number of 'ancillary services' are being covered by the tonnage tax schemes of EU countries (ITF 2019), a maximum of half of the profits of these activities can be covered by tonnage taxes according to the EU Maritime State Aid Guidelines, and the other half would still need to be taxed at regular rates.

In container shipping, as in bulk shipping, there is a clear distinction between non-operating shipowners, mostly incorporated in zero-tax jurisdictions, and owners that are also operators who are incorporated in a wider set of jurisdictions, mostly non-zero-tax jurisdictions. Especially in the bulk sectors, a substantial part of the 


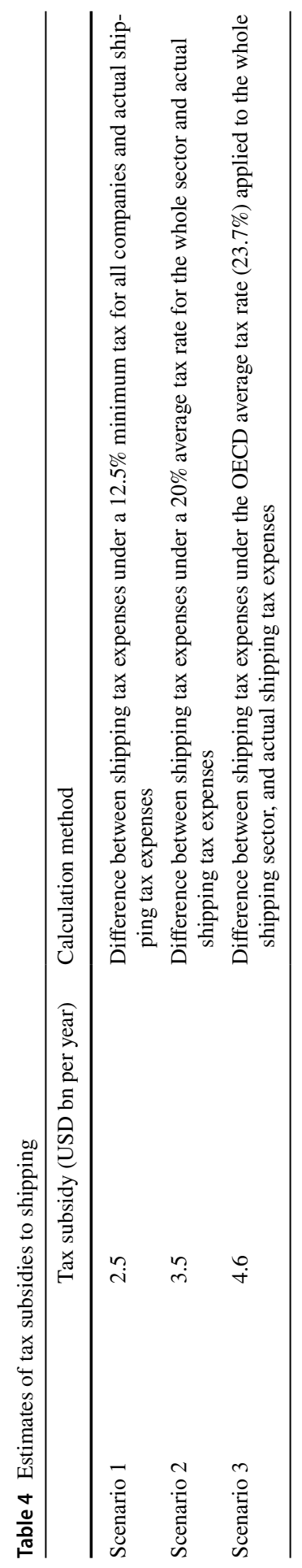

s. 
shipping companies pay practically zero taxes, but the remaining companies pay considerable amounts of tax.

Although certain Asian countries provide large direct subsidies to their shipping sector or shipyards, they also generally impose the highest effective tax rates on their shipping sector, higher than the average in Europe. Some jurisdictions in Europe provide practically zero taxation for shipowners, e.g. in Monaco. Maritime subsidies in Asia might be distorting competition in shipping, but one could wonder whether these are of the same order of magnitude as the tax subsidies provided by the likes of Marshall Islands, Liberia and Bermuda. The complaints of shipowner associations vis-à-vis maritime subsidies in South Korea and China seem to be selective and possibly misdirected.

\section{Conclusions and policy implications}

Tax subsidies to shipping have become more important over the last decades, but no estimates exist on how much public money is spent (tax revenues foregone) on this. A tax subsidy that is particularly difficult to quantify due to data limitations is related to corporate income tax, which was the focus of this editorial. In order to fill this data gap, we constructed a new dataset made up of data collected from annual financial reports of 157 shipping companies over the period 2005-2019. Our data collection exercise meant to fill a data gap with regard to tax subsidies and also illustrate the need to expand the data collection on and the analysis of tax subsidies for the shipping industry. Governments could monitor the tax expenditures related to shipping more closely by regularly analysing the profits of their shipping firms. Such exercises could help to determine the impact of tax subsidies on the shipping sector. This is all the more relevant when shipping companies are also involved in non-shipping activities.

This diversification of shipping companies could also distort markets related to logistics and port terminal operations. Tonnage tax schemes in at least a dozen countries allow terminal operations carried out for a ship under a tonnage tax scheme to be covered under the scheme as well. Such a provision benefits shipping companies that own terminal subsidiaries, as they can lower their tax burden compared with independent terminal operators not subject to the tonnage tax regime. A similar distortion could exist in freight forwarding and logistics activities carried out by container shipping companies. The effects of such distortions could be substantial; our analysis shows that the effective tax rates for freight forwarders, logistics operators and port terminal operators is two to three times higher than that of the shipping sector as a whole. Moreover, we find that the average tax rate for terminal operators that are vertically integrated with shipping companies is $14 \%$, whereas the average tax rate for non-integrated terminal operators is $21 \%$ (Table 5). We have been able to conduct this analysis by assessing the data for various shipping companies that also operate terminals and present the profits and tax expenses for terminal operations in their segment reporting.

Our analysis also shows that there is no level playing field regarding the shipping taxation regimes around the world. We estimate that the global shipping industry as 
Table 5 Effective tax rates of integrated and non-integrated terminal operators
Effective

tax rate $(\%)$

\begin{tabular}{lr} 
Vertically integrated terminal operator & 14 \\
Non-integrated terminal operator & 21 \\
Terminal operators (total) & 20 \\
Shipping & 7 \\
\hline
\end{tabular}

a whole has an effective corporate income tax rate of $7 \%$, but we also find that the majority (57\%) of the companies in our database had zero corporate tax expenses. Moreover, there are considerable differences between world regions, ranging between zero taxation in Oceania and North America to $11 \%$ for shipping companies incorporated in Europe, and $12 \%$ for those incorporated in Asia. This global tax competition results in a continued hollowing out of government tax revenues related to shipping activities. According to our estimates, the shipping sector paid USD 1.9 billion per year in corporate taxes. Depending on methodology and assumptions, tax subsidies to the shipping sector range between USD 2.5 and USD 4.6 billion per year. Even in Europe-where the corporate tax revenues from shipping are relatively high-corporate tax subsidies to the shipping sector exceed the revenues from shipping taxation. Moreover, shipping tax havens (open registries) are also often used by shipowners to limit tax obligations and help to diffuse responsibility in case of accidents and environmental disasters. Reconsideration of the global regulatory architecture for shipping is warranted, and this should include shipping taxation matters. 


\section{Annex: Companies included in our database}

Shipping firms

Port terminal operators
2GO Group, Aboitiz Transport System, American Shipping Corporation, Ardmore, Attica Holdings, Avance Gas Holdings, Bahri, Belships, Box Ships, BW LPG, Capital Product Partners, Carnival, Castor Maritime, CH Offshore, Chang Jiang Shipping Group, China COSCO Shipping, China Merchants Energy Shipping, Chinese Maritime Transport Ltd, CMA CGM, Color Group, Concordia Maritime, Costamare, Courage Investment Group, CSAV, D'Amico International Shipping, Danaos, DFDS, DHT, Diana Containerships, Diana Shipping Inc, Dorian LPG, Dynagas LNG Partners, Eagle Bulk Shipping, Eimskip, Eitzen Bulk Shipping, Essar Shipping, Eurodry, Euronav, Euroseas,Evergreen Marine Corporation, Exmar LNG, Exmar LPG, Exmar Offshore, Finnlines, First Ship Lease Trust, Fjord Line, Gas Log, Gas Log Partners, GC Rieber, Genco Shipping \& Trading, Global Ship Lease, Globus Maritime, Golar LNG, Golar LNG Partners, Golden Ocean, Good Bulk, Great Eastern Shipping, Great Harvest Maeta Group, Grieg Star, GSD Denizcilik, Gulf Navigation Holding, Hafnia, Hapag Lloyd, Hoegh LNG, Humpuss Intermoda Transportasi, Iino Kaiun Kaisha, International Seaways, Irish Continental Group, J. Lauritzen, Jinhui Holdings, Jordan National Shipping Lines, KNOT Offshore Partners, Korea Line Corp, KSS Line, Kyoei Tanker Corporation, Lorenzo Shipping Corporation, Maersk Line, Maersk Supply Service, Maersk Tankers, Malaysian Bulk Carriers Berhad, Matson, Minoan Lines, MSC Cruise, Navig8 Chemical Tankers, Navigator Holdings, Navios Maritime Acquisitions, Navios Maritime Containers, Navios Maritime Partners, Norden, Nordic American Tankers, Nordic Shipholding, North-Western Shipping, Norwegian Cruise Line, NS United Kaiun Kaisha Ltd, Ocean Yield, Odfjell, OOIL, Overseas Shipholding Group, Pacific Basin, Pan Ocean Corporation, Pangaea Logistics Solutions, Polaris Shipping, Precious Shipping, PT Trans Power Marine, Pyxis Tankers, Royal Arctic Line, Royal Caribbean International, Safe Bulkers, SBM Offshore, Scandlines, Scorpio Bulkers, Scorpio Tankers, Seanergy Maritime, Seaspan, Seroja Investments, Ship Finance International, Shipping Corporation of India, Shreyas Shipping, Sillo Maritime Perdana, Singapore Shipping Corporation, SITC, Soechi Lines, Solvang ASA, Sovcomflot, Star Bulk, StealthGas, Stolt Nielsen, Tallink, Tamai Steamship Company, Team Tankers International, Teekay LNG Partners, Teekay Tankers, Temas Line, Thoresen Thai Agencies, Top Ships, Torm, Torvald Klaveness, Tsakos Energy Navigation, Ultrabulk, U-Ming Marine Transport, Uni-Asia Group, Unifeeder, Viking Line, Viking Supply Ships, Wallenius Wilhelmsen, Wanhai Lines, Wilh. Wilhelmsen Holding, Wilson ASA, Winland Ocean Shipping, Wisdom Marine and Yang Ming

Adani Ports, APMT, Asian Terminals, Beibu Gulf Port, China Merchants Port Holdings, COSCO Pacific, COSCO Shipping Ports, Dalian Port Company, DP World, Essar Ports, Eurokai, Global Port Investments, Global Port Holdings, Global Ports, Gujarat Pipavav Port, HHLA, Hutchison Port Holdings Trust, ICTSI, Jiangsu Lianyungang Port, Jinzou Port, Koninklijke Vopak, Luka Koper, Nanjing Port, Ningbo Zhoushan Port, Novorossiysk Commercial Sea Port, Piraeus Port Authority, Port of Tauranga, PSA, Puerto Ventanas, Qingdao Port International, Qinhuangdao Port, Rizhao Port Company, SAAM, Salalah Port Services Co, Shanghai International Port Group, South Port New Zealand, Tangshan Port Group, Thessaloniki Port Authority, Tianjin Port Development Holdings, Xiamen International Port Company and Yingkou Port Liability Company; 
Freight forwarders/ logistics operators
ABC India Ltd, Azuma Shipping, Damco, DSV Panalpina, Ever Harvest Group, Far Eastern Shipping, Fushiki Kairiku Unso, Grup Empresas Navieras, Grupo TMM, HNA Technology, Hyoki Kaiun Kaisha, Kuehne \& Nagel, Kuribayashi Steamship Company, Naigai Trans Line, Ningbo Marine Co, Ocean Wilsons Holdings, PT Samudera Indonesia, SAAM, Sakurajima Futo Kaisha, Salam International Transport \& Trading, Santova, Sinotrans, Tegma Gestao Logistica SA and Tokyo Kisen Co

\section{References}

Bergantino, A., and P. Marlow. 1998. Factors influencing the choice of flag: empirical evidence. Maritime Policy and Management 25: 157-174.

Bergin, Tom. 2015. The Greek Shipping Myth; How Greek shipowners talk up their role, and why that costs Athens millions. Reuters, 25 November 2015.

Bernhofen, Daniel, Zouheir El-Sahli, and Richard Kneller. 2016. Estimating the effects of the container revolution on world trade. Journal of International Economics 98: 36-50.

Brooks, M., and R. Hodgson. 2005. The fiscal treatment of shipping: A Canadian perspective on shipping policy. Research in Transportation Economics 12: 143-171.

Brownrigg, M., et al. 2001. Developments in UK shipping: The tonnage tax. Maritime Policy \& Management 28: 213-223.

Carlisle, R. 1981. Sovereignty for sale: The origins and Evolution of the Panamanian and Liberian Flags of Convenience. New York: Naval Institute Press.

Carlisle, Rodney. 2017. Rough waters sovereignty and the American Merchant Flag. Annapolis: Naval Institute Press.

CEBR. 2017. The economic impact of the Tonnage tax regime on the shipping industry; A report for Maritime UK. London: Centre for Economics and Business Research.

Chiu, R. 2007. The liberalization of shipping in Taiwan. Marine Policy 31: 258-265.

Cullinane, Kevin, and Mahim Khanna. 1999. Economies of scale in large containerships. Journal of Transport Economics and Policy 33: 185-208.

Cullinane, Kevin, and Mahim Khanna. 2000. Economies of scale in large containerships: optimal size and geographical implications. Journal of Transport Geography 8: 181-195.

Danish Economic Council. 2006. Dansk Okonomi, Forar 2006" (Danish Economy, Spring 2006). Copenhagen, Denmark: Det Okonomiske Rad.

Deloitte Consulting. 2006. Fiscale monitor zeescheepvaart 2005 (Fiscal monitor ocean shipping 2005) for Netherlands Ministry of Transport and Water. Utrecht: Deloitte Consulting.

EC. 1997. Community guidelines on State aid to maritime transport. Official Journal of the European Union, 1997/C 205/5. Brussels: European Commission.

EC. 2004. Community guidelines on state aid to maritime transport. Official Journal of the European Union, 2004/C 13/03. Brussels: European Commission.

EC. 2010. State aid-N-37/2010 Cyprus; Introduction of a tonnage tax scheme in favour of international maritime transport, C (2010) 1727 final. Brussels: European Commission.

EC. 2017. Commission decision of 19.12 .2017 on State aid SA.33829 (2012/C), Maltese tonnage tax scheme and other State measures in favour of shipping companies and their shareholders, C(2017) 8734 final. Brussels: European Commission.

EC. 2019. State aid SA.51809 (2019/N)_Cyprus, prolongation of the cyprus tonnage tax and seafarer scheme. Brussels: European Commission.

EC. 2020. White paper on foreign subsidies. Brussels: European Commission.

Econ. 2010. Evaluering av sysselsettingsordningene for sjofolk. Econ-report No. 2010-023. For the Norwegian Ministry for Economy and Trade.

Ecorys. 2007a. Telefonische enquête reders inzake evaluatie ingezet fiscaal stimuleringspakket zeevaart (Phone survey of shipowners regarding evaluation of deployed fiscal support package ocean shipping) for Netherlands. Rotterdam: Ministry of Transport and Water.

Ecorys. 2007b. Kwantitatieve analyse fiscal regelingen zeescheepvaart (Quantitative analysis of fiscal measures in ocean shipping) for Netherlands. Rotterdam: Ministry of Transport and Water. 
EFTA. 2017. The Norwegian Special tax system for shipping 2018-2027. Brussels: EFTA Surveillance Authority.

Elschner, Christina. 2009. Tonnagebesteuerung. In Evaluierung von Steuervergünstigungen. Band 3: Evaluierungsberichte (zweiter Teilband), ed. Anna Jung et al. ZEW.

Evans, J. 1984. Some practical aspects of investment appraisal in shipping. Maritime Policy and Management 11: 197-222.

EY. 2016. Shipping Industry Almanac 2016. https://www.ey.com/Publication/vwLUAssets/EY-shippingindustry-almanac-2016/\$FILE/EY-shipping-industry-almanac-2016.pdf. Assessed 2 Sept 2019.

Farr, Albert. 2014. Taxation of marine shipping income: A critique of US tax laws in the energy transport industry. Tulane Maritime Law Journal 39: 221-240.

Gardner, B. 1975. Investment grants and balance of payment tests. Maritime Studies and Management 2: 221-230.

Gardner, B., and P. Marlow. 1983. An international comparison of the fiscal treatment of shipping. The Journal of Industrial Economics 31: 397-415.

Gardner, B., and P. Richardson. 1973. The fiscal treatment of shipping. The Journal of Industrial Economics 22: 95-117.

Gekara, V. 2010. The stamp of neoliberalism on the UK tonnage tax and the implications for British seafaring. Marine Policy 34: 487-494.

Gibbs, Margot. 2017. The tax-free shipping company that took control of a country's UN mission. Climate Home News, 6 July 2017.

Glen, D. 1996. The econometric testing of investment incentives: A cointegrated approach. Maritime Policy and Management 23: 201-207.

Goss, R., and P. Marlow. 1993. Internationalism, protectionism and interventionism in shipping. In Current issues in maritime economics, ed. K. Gwilliam. Dordrecht: Kluwer.

Haralambides, Hercules. 1989. Shipping transactions in the balance of payments statistics: A tabular approach. Marine Policy Reports 1: 119-134.

Haralambides, Hercules. 2019. Gigantism in container shipping, ports and global logistics: A time-lapse into the future. Maritime Economics \& Logistics 21 (1): 1-60.

Harley, C.K. 1988. Ocean freight rates and productivity, 1740-1913: The primacy of mechanical invention reaffirmed. Journal of Economic History 48: 851-876.

Hummels, David. 2007. Transportation costs and international trade in the second era of globalization. Journal of Economic Perspectives 21 (3): 131-154.

ICS. 2020. Annual Review 2019. London: International Chamber of Shipping.

IMDO. 2010. Report on the Irish Tonnage Tax 2009; relating to EU maritime state aids. Dublin: Ireland Maritime Development Office.

IMDO. 2011. Report on the Irish Tonnage Tax 2010; relating to EU maritime state aids. Dublin: Ireland Maritime Development Office.

Intracorp. 2014. Cámara Marítima de Panamá; Estudio de Impacto Económico (Maritime Chamber of Panama; Economic Impact Study") Panamá. Vancouver: Intracorp.

ITF. 2015. The impact of mega-ships. International transport forum. Paris: OECD.

ITF. 2019. Maritime subsidies; Do they provide value for money? International transport forum. Paris: OECD.

Jannson, J., and D. Shneerson. 1982. The optimal ship size. Journal of Transport Economies and Policy 16 (3): 217-238.

Jantscher, Gerald. 1975. Bread upon the Waters: Federal Aids to the Maritime Industries. Washington, DC: The Brookings Institution.

Jones, Grosvenor. 1916. Government aid to merchant shipping; Study of subsidies, subventions, and other forms of state aid in principal countries of the world. Special agents series, no. 119. Washington, DC: US Department of Commerce, Bureau of Foreign and Domestic Commerce.

Kavussanos, M., and A. Tsekrekos. 2011. The option to change the flag of a vessel. In International handbook of maritime economics, ed. K. Cullinane, 47-62. Cheltenham: Edgar Elgar Publishing.

Kerem Cosar, A., and Banu Demir. 2018. Shipping inside the box: Containerization and trade. Journal of International Economics 114: 331-345.

Knauerhase, Ramon. 1968. The compound steam engine and productivity changes in the German merchant marine fleet, 1871-1887. The Journal of Economic History 28: 390-403.

Knudsen, K. 1997. The economics of zero taxation of the world shipping industry. Maritime Policy and Management 24: 45-54. 
Lawrence, Samuel. 1966. United States merchant shipping policies and politics. Washington, DC: The Brookings Institution.

Leggate, H., and J. McConville. 2005. Tonnage tax: is it working? Maritime Policy \& Management 32: 177-186.

Levinson, Marc. 2006. The box-How the shipping container made the world smaller and the world economy bigger. Princeton: Princeton University Press.

Lottum, Jelle Van, and Jan Luiten van Zanden. 2014. Labour productivity and human capital in the European maritime sector of the eighteenth century. Explorations in Economic History 53: 83-100.

Luiten, Van Zanden Jan., and Milja van Tielhof. 2009. Roots of growth and productivity change in Dutch shipping industry, 1500-1800. Explorations in Economic History 46: 389-403.

Maisto, G. (ed.). 2017. Taxation of shipping and air transport in domestic law, EU law and tax treaties. IBFD EC and International Tax Law Series, vol. 15.

Marlow, P. 1991. Shipping and investment incentives: A trilogy; Part 1. Investment incentives for industry. Maritime Policy \& Management 18: 123-138.

Marlow, P. 1991. Shipping and investment incentives: A trilogy; Part 2. Investment incentives for shipping. Maritime Policy \& Management 8: 201-216.

Marlow, P. 1991. Shipping and investment incentives: A trilogy; Part 3. The effectiveness of investment incentives for shipping-The UK experience 1950-1987. Maritime Policy \& Management 18: 283-311.

Marlow, P., and K. Mitroussi. 2008. EU shipping taxation: The comparative position of Greek shipping. Maritime Economics \& Logistics 10: 185-207.

Marlow, P., and K. Mitroussi. 2011. Shipping taxation: perspectives and impact on flag choice. International Journal for Shipping and Transport Logistics 3: 349-364.

Marlow, P., and K. Mitroussi. 2012. Shipping taxation. In The Blackwell companion to maritime economics, ed. W. Talley. Hoboken: Blackwell Publishing.

Matsos, G. 2009. Tonnage tax and tax competition. In Competition and regulation in shipping and shipping related industries, ed. A. Antapassis, L. Athanassiou, and E. Rosaeg. London: Brill International Law Books.

Mayr, T., and R. McGrath. 1997. Tramp shipping: The role of taxation in international resource allocation. Maritime Policy and Management 24: 261-283.

McWilliams, D., P. Norwood, and A. Parfitt. 1995. Econometric testing of investment incentives: Update of Marlow model. Maritime Policy and Management 22: 265-275.

Meeker, Royal. 1905. History of shipping subsidies. New York: American Economic Association, Macmillan Company Columbia University.

Merika, Anna, Triantafyllou Anna, and George Zombanakis. 2019. Wage and tax competitiveness: The case of Hellenic shipping. Transportation Research Part A: Policy and Practice 119: 255-270.

Milanovic, Branko. 2019. Capitalism, alone: The future of the system that rules the world. Cambridge, MA: The Belknap Press of Harvard University Press.

Moyer, C. 1977. Maritime subsidies: Problems, alternatives and tradeoffs. The Journal of Industrial Economics 26: 53-68.

Naess, Erling. 1972. The great PanLibHon controversy: The fight over the flags of shipping. Aldershot: Gower.

North, Douglass. 1958. Ocean freight rates and economic development 1750-1913. Journal of Economic History 18: 537-555.

North, Douglass C. 1968. Sources of productivity change in ocean shipping, 1600-1850. Journal of Political Economy 76 (5): 953-970.

North, Douglass. 1991. Institutions, transaction costs and the rise of merchant empires. In The political economy of merchant empires; State power and world trade, ed. James Tracy, 1350-1750. Cambridge: Cambridge University Press.

OECD. 2020. Tax challenges arising from digitalisation-Report on the Pillqr two blueprint; inclusive framework on BEPS. OECD/G20 Base Erosion and Profit Shifting Project. Paris: OECD.

O'Rourke, Kevin H., and Jeffrey G. Williamson. 1999. Globalization and history: The evolution of a nineteenth-century Atlantic economy. Cambridge, MA: MIT Press.

Panagiotou, Stelios, and Helen Thanopoulou. 2019. Tonnage Tax revisited: The case of Greece during a shipping crisis and an economic crisis period. Bank of Greece working paper, 266, July 2019

Panteia. 2014. Evaluatie van de fiscale maatregelen in het zeevaartbeleid (Evaluation of the fiscal measures in shipping policy) Zoetermeer. 
Pascali, Luigi. 2017. The wind of change: Maritime technology, trade, and economic development. American Economic Review 107: 2821-2854.

Republic of the Marshall Islands. 2016. Budget Book 2016-2021.

Rodrik, Dani. 2018. Straight talk on trade: Ideas for a sane world economy. Princeton: Princeton University Press.

Saez, Emanuel, and Gabriel Zucman. 2019. The triumph of injustice: How the rich dodge taxes and how to make them pay. New York: W.W. Norton \& Co.

Saugstad, J. 1932. Shipping and shipbuilding subsidies: A study of state aid to the shipping and shipbuilding industries in various countries of the world. Trade promotion series, no. 129. Washington, DC: US Department of Commerce, Bureau of Foreign and Domestic Commerce.

Selkou, E., and M. Roe. 2002. UK tonnage tax: Subsidy or special case? Maritime Policy \& Management 29: 393-404.

Siegert, F. 1930. Die Subventionen der Weltschiffahrt und ihre sozialökonomischen Wirkungen. Berlin: Springer.

Sletmo, G. 2001. The end of national shipping policy? A historical perspective on shipping policy in a global economy. International Journal of Maritime Economics 3: 333-350.

Stevens, T. 2017. Taxation of shipping transport activities (including tonnage tax systems). In Taxation of shipping and air transport in domestic law, EU law and tax treaties, vol. 15, ed. G. Maisto. Amsterdam: IBFD EC and International Tax Law Series.

Sturmey, S.G. 1975. Shipping economics: Collected papers. New York: Macmillan.

Trafikanalys. 2019. Sjöfartstödet effekter 2018 (Effects of support to shipping 2018). Rapport 2019:14. Stockholm: Trafikanalys.

UK Representative to the EU. 2006-2009 and 2014. Annual report on the UK Tonnage Tax for the European Commission.

Wan, H. 1988. The effects of the Chinese fiscal regime on shipping: A comparison with the UK regime. Maritime Policy and Management 15: 299-308.

Weber, D., and M. Van de Sande. 2017. Tonnage tax and EU law. In Taxation of shipping and air transport in domestic law, EU law and tax treaties, vol. 15, ed. G. Maisto. Amsterdam: IBFD EC and International Tax Law.

Yang, Y. 2014. Effect of shipping aid policies on the competitive advantage of national flagged fleets: Comparison of Taiwan, Korea and Japan. Transport Policy 35: 1-9.

Zucman, Gabriel. 2013. The missing wealth of nations: Are Europe and the U.S. net debtors or net creditors? The Quarterly Journal of Economics 128: 1321-1364.

Zucman, Gabriel. 2015. The hidden wealth of nations: The scourge of tax havens. Chicago: University of Chicago Press.

Publisher's Note Springer Nature remains neutral with regard to jurisdictional claims in published maps and institutional affiliations. 